\title{
Comprehensive assessment of red currant varieties in Altai
}

\author{
Nadezhda Nazaryuk $^{1}$, Vladimir Sorokopudov ${ }^{2,}$, , Olga Sorokopudova ${ }^{2}$, and Radmil \\ Nigmatzyanov ${ }^{3,4}$ \\ ${ }^{1}$ Federal Altai Scientific Centre of Agro-Bio Technologies, 656910 Barnaul, Russian Federation \\ ${ }^{2}$ Russian State Agrarian University - Moscow Timiryazev Agricultural Academy, 127550 Moscow, \\ Russian Federation \\ ${ }^{3}$ Ufa Federal Research Centre of the Russian Academy of Sciences, 450054 Ufa, Russian Federation \\ ${ }^{4}$ Institute of Strategic Studies of Bashkortostan Republic, 450008 Ufa, Russian Federation
}

\begin{abstract}
Red currant (Ribes rubrum L.) is a berry crop promising for cultivation in Siberia. The purpose of the work was to study the elements of productivity and biochemical composition of fruits in 17 varieties of $R$. rubrum of various origins of the VNIISPK breeding. This article presents the results of the study of red currant varieties selected by VNIISPK in the Altai. Most varieties are highly resistant to gall aphids, with the exception of 'Valentinovka', 'Orlovskaya Zvezda' and 'Orlovchanka ' - in some years, their damage was noted to a very weak degree. As sources of valuable biochemistry, the following varieties were identified: with a high content of soluble dry substances - Asya, Bayana, Vika, Dar Orla, Marmeladnitsa, Osipovskaya; sugar - Asya, Bayana, Roza; vitamin C Asora, Asya, Protein, Vika, Marmeladnitsa, sugar-acid index - Asora, Orlovchanka, Roza. The varieties Asora, Asya, Bayana, Valentinovka, Vika, Dana, Dar Orla, Marmeladnitsa, Orlovskaya Zvezda, Orlovchanka, Osipovskaya, and Roza were identified according to the complex of economically useful traits (yield, large-fruited, biochemical composition, resistance to harmful organisms), which can be recommended for cultivation in the conditions of the Altai Ob region.
\end{abstract}

\section{Introduction}

Red currant (Ribes rubrum L.) is a berry crop promising for cultivation in Siberia, although the area occupied by it is much smaller than other berry crops. Red currant fruits are characterized by an optimal combination of vitamins, sugars, organic acids, pectin and nitrogenous matters, which determines the possibility of their wide use in medical and dietary nutrition, consumption in fresh and processed form [1-3].

Red currant is drought-resistant and weakly susceptible to damage by diseases and pests. Plants of $R$. rubrum in comparison with $R$. nigrum L. have a longer generative period and can bear fruit for up to 25 years with proper agricultural techniques. All these qualities characterize red currant as a berry crop, valuable for gardening [4-5].

\footnotetext{
* Corresponding author: sorokopud2301@mail.ru
} 
Research on the introduction and selection of red currant in the last few decades has significantly intensified in Russia, the CIS countries and the world as a whole. A significant number of varieties of domestic and foreign selection have been created [6-10]. Currently, there are more than 160 varieties of red currant in the world. At the same time, the State Register of the Russian Federation includes 42 varieties of red currant, 10 - white currant, of which for the European part of Russia 12 varieties $(28.6 \%)$ of red currant and 1 variety $(10.0 \%)$ of white currant of the VNIISPK breeding - the leading center of $R$. rubrum domestic breeding; for the West Siberian region, which includes Altai, 19 (45.2\%) varieties of red currant are included, of which $9(21.4 \%)$ are of the VNIISPK breeding [11]. The prospect of involving red currant forms from different geographical zones in breeding is emphasized by many authors [12-15]. The selection of varieties adapted to local conditions is a prerequisite for increasing the crop productivity. Therefore, the study of the biological characteristics of $R$. rubrum varieties in the Altai region is of particular relevance. The purpose of the work was to study the elements of productivity and biochemical composition of fruits in 17 varieties of $R$. rubrum of various origins of the VNIISPK breeding.

\section{Materials and methods}

The work on variety testing is carried out in the FSBSI FANCA "NIISS" Department in accordance with the Program and methodology of variety research of fruit, berry and nut crops [16].

As a result of almost forty years of breeding work on red currant in the FSBSI AllRussian Research Institute of Fruit Crop Breeding (VNIISPK, city of Orel) breeders L.V. Bayanova, O.D. Golyaeva, V.E. Jafarova, N.S. Levgerova, M.A. Makarkina, A.V. Petrov bred more than 20 varieties [17, 18], of which 7 were transferred to the State Variety Testing - 'Belka' (1996), 'Ogonyok' (2007), 'Orlovskaya Zvezda' (2001), 'Roza' (2001), 'Selyanochka' (2011), 'Premyera' (2019), 13 varieties are included in the State Register of the Russian Federation and are approved for use in six regions of Russia: Central, VolgaVyatka, Central Chernozem, Middle Volga, West Siberian and Far East regions. The varieties 'Asya', 'Vika', 'Gazelle', 'Dana', 'Dar Orla', 'Marmeladnitsa', 'Niva', 'Orlovchanka', 'Podarok Leta' are approved for use in the West Siberian region.

The red currant varieties 'Asora', 'Asya', 'Bayana', 'Belka', 'Valentinovka', 'Vika', 'Gazelle', 'Dana', 'Dar Orla', 'Marmeladnitsa', 'Orlovskaya Zvezda', 'Orlovchanka', 'Osipovskaya', 'Roza', 'Ustina' of VNIISPK breeding were planted in the city of Barnaul in October 2003, varieties 'Ogonyok', Podarok Leta' - in autumn 2008.

\section{Results and discussions}

In the years of research in the Altai, the weather conditions in autumn and winter according to the weather station of the Research Institute of Horticulture of Siberia named after M.A. Lisavenko turned out to be not quite favorable for berry plants overwintering. The absolute minimum air temperature in December-February $2010-2019$ was $-39.5{ }^{\circ} \mathrm{C} ;-37.5^{\circ} \mathrm{C} ;-38.0$ ${ }^{\circ} \mathrm{C} ;-41.0{ }^{\circ} \mathrm{C} ;-33.0{ }^{\circ} \mathrm{C} ;-35.5{ }^{\circ} \mathrm{C} ;-29.0{ }^{\circ} \mathrm{C} ;-30.0{ }^{\circ} \mathrm{C} ;-36.8{ }^{\circ} \mathrm{C} ;-37.0{ }^{\circ} \mathrm{C}$, respectively; in little-snow November $2016,2019-32.2^{\circ} \mathrm{C}$ and $-28.5^{\circ} \mathrm{C}$; on the snow surface $-45.5^{\circ} \mathrm{C}$. The currant plants overwintered quite satisfactorily. The assessment of the plant condition in spring and summer was 3.0-5.0 points, with an average of 4.5 points.

Early spring with high air temperatures in April (maximum levels in April 2010-2020: $25.0{ }^{\circ} \mathrm{C} ; 24.0{ }^{\circ} \mathrm{C} ; 25.5{ }^{\circ} \mathrm{C} ; 21.2{ }^{\circ} \mathrm{C} ; 25.5{ }^{\circ} \mathrm{C} ; 22.5{ }^{\circ} \mathrm{C} ; 27.5^{\circ} \mathrm{C} ; 27.3{ }^{\circ} \mathrm{C} ; 20.0{ }^{\circ} \mathrm{C} ; 23.0{ }^{\circ} \mathrm{C}$ and $29.5{ }^{\circ} \mathrm{C}$, respectively) contributed to the early flowering of red currant, which was noted at the beginning of the first decade of May. The weather conditions at this time were 
not quite favorable for berry setting. The minimum humidity in April 2010-2020 was $28,0 \%, 31,0 \%, 27,0 \%, 42,0 \%, 18,0 \%, 33,0 \%, 32,0 \%, 30,0 \%, 35,0 \%, 26,0 \%, 27,0 \%$ accordingly. Nevertheless, the degree of flowering in the varieties was satisfactory and good $-3.0-5.0$ points, with the exception of the Ogonyok variety $(2.0-4.0$ points, average 3.2 points). The berry setting was marked by 3.0-5.0 points, with an average of 3.8 . The best berry setting was observed in the varieties Bayana, Valentinovka (4.0-4.5 points); Dana, Dar Orla (3.5-5.0 points), on average from 4.1 to 4.3 points.

Over the years of research, the degree of fruiting for varieties ranged from 2.0 points (Gazelle, Ogonyok, Podarok Leta, Ustina) to 5.0 points (Dana, Dar Orla), the average -3.8 points. The maximum degree of fruiting was shown by the varieties Asora, Asya, Bayana, Valentinovka, Vika, Dana, Dar Orla, Orlovchanka, Osipovskaya (4.5-5.0 points). The number of flowers in the raceme varied from 9.9 pcs. in the Roza variety, up to 28.6 pcs. in the Valentinovka variety, the number of berries - from 2.6 pcs. in the Gazelle variety, up to 21.7 pcs. in the Orlovskaya Zvezda variety (Table 1).

Table 1. Average indicators of the elements of red currant varieties productivity, 2009-2020

\begin{tabular}{|c|c|c|c|c|}
\hline \multirow{2}{*}{ Variety } & \multicolumn{2}{|c|}{ Quantity per raceme, pcs. } & \multicolumn{2}{|c|}{ Berry weight, $g$} \\
\hline & flowers & berries & average & $\max$ \\
\hline Asora & $\frac{13.1}{10.7-15.8}$ & $\frac{6.2}{2.9-10.6}$ & $\frac{0.7}{0.6-0.9}$ & $\frac{1.1}{9-1.3}$ \\
\hline Asya & $\frac{13.5}{10.5-17.5}$ & $\frac{6.4}{3.8-12.1}$ & $\frac{0.6}{0.5-0.8}$ & $0.8-1.1$ \\
\hline Bayana & $\frac{18.2}{16.4-20.5}$ & $8.8-15.2$ & $0 . \frac{0.5}{4-0.6}$ & $0.7-1.2$ \\
\hline Belka & $10 \frac{11.9}{3-13.3}$ & $\frac{7.0}{4.5-9.8}$ & $0 . \frac{0.6}{3-0.8}$ & $0 . \frac{0.9}{5-1.4}$ \\
\hline Valentinovka & $\frac{21.8}{18.2-28.6}$ & $9 . \frac{13.8}{9-18.4}$ & $\frac{0.6}{0.5-0.8}$ & $0.8-1.2$ \\
\hline Vika & $\frac{13.1}{11.6-15.8}$ & $\underline{6.7-11.7}$ & $0 . \frac{0.5}{4-0.6}$ & $0.7-1.0$ \\
\hline Gazelle & $\frac{15.3}{11.9-19.5}$ & $\frac{6.6}{2.6-12.0}$ & $0.0 .6-0.7$ & $0.0 .9-1.1$ \\
\hline Dana & $\frac{20.9}{17.2-26.9}$ & $7.1-17.4$ & $\frac{0.7}{0.6-0.8}$ & $0.9-1.4$ \\
\hline Dar Orla & $\frac{21.4}{17.0-27.1}$ & $5 . \frac{10.7}{6-16.4}$ & $\frac{0.6}{0.5-0.8}$ & $0.8-1.4$ \\
\hline Marmeladnitsa & $12.9-18.5$ & $\frac{5.9}{4.0-12.4}$ & $0.5-0.6$ & $0.0 .9-1.1$ \\
\hline Ogonyok & $\frac{18.1}{15.0-22.2}$ & $\frac{8.7}{4.8-14.1}$ & $0.3-0.5$ & $0 . \frac{0.8}{6-1.0}$ \\
\hline $\begin{array}{l}\text { Orlovskaya } \\
\text { Zvezda }\end{array}$ & $\frac{21.9}{11.4-26.7}$ & $5.11-21.7$ & $\frac{0.7}{0.6-0.9}$ & $1.0-1.6$ \\
\hline Orlovchanka & $\frac{17.9}{16.1-20.1}$ & $\frac{9.8}{6.3-14.6}$ & $0.0 .6-0.7$ & $0.8-1.2$ \\
\hline Osipovskaya & $\frac{17.4}{14.1-22.6}$ & $6.4-15.5$ & $0 . \frac{0.5}{4-0.7}$ & $0.8-1.5$ \\
\hline Podarok Leta & $\frac{20.2}{16.3-24.3}$ & 3.10 .0 & $0.3-0.7$ & $0.7-1.1$ \\
\hline Roza & $9.9-15.3$ & $5.0 .6-9.2$ & $\frac{0.6}{0.5-0.8}$ & $0 . \underline{0.9}$ \\
\hline Ustina & $\frac{17.9}{14.5-20.6}$ & $\frac{8.9}{5.4-13.5}$ & $0.3-0.6$ & $0 . \frac{0.7}{5-0.8}$ \\
\hline Average & $9 \frac{17.1}{9-28.6}$ & $\frac{9.1}{2.6-21.7}$ & $\underline{0.6}$ & 0.0 .9 \\
\hline
\end{tabular}

Note: in the numerator - the average long-term value of the trait $(M)$, in the denominator - the variation of $M$ in the years of research (min-max). 
The varieties Asora, Asya, Valentinovka, Dana, Dar Orla, Orlovskaya Zvezda, and Roza with an average berry weight of $0.5-0.9 \mathrm{~g}$ and a maximum of 1.1-1.6 $\mathrm{g}$ were distinguished by their large-fruitness.

Most varieties are highly resistant to gall aphids, with the exception of 'Valentinovka', 'Orlovskaya Zvezda' and 'Orlovchanka ' - their affection in 2013, 2015-2020 was noted to a very weak degree (0.1-0.5 points).

The content of soluble solid matters varied from $8.0 \%$ (Vika) to $14.9 \%$ (Marmeladnitsa); sugars - from 4.7\% ('Vika') to 11.6\% ('Bayana'); acids - from $0.9 \%$ ('Asora', 'Orlovchanka', 'Rosa') to 3.2\% ('Asya', 'Orlovskaya Zvezda') (Table 2). The sugaracid index varied from 1.7 ('Asya') to 11.9 ('Roza'), with an average of 4.2. The vitamin C content varied from $17.0 \mathrm{mg} / 100 \mathrm{~g}$ ('Roza') to $104.0 \mathrm{mg} / 100 \mathrm{~g}$ ('Asya').

Table 2. Biochemical composition of berries of red currant varieties, 2009-2019

\begin{tabular}{|c|c|c|c|c|c|}
\hline \multirow[b]{2}{*}{ Variety } & \multicolumn{5}{|c|}{ Indicator } \\
\hline & SSM, \% & Sugars, \% & Acids, \% & SAI & $\begin{array}{c}\text { Vitamin C, } \\
\mathrm{mg} / 100 \mathrm{~g}\end{array}$ \\
\hline Asora & $10 \frac{12.1}{7-13.6}$ & $\frac{8.4}{6.9-9.8}$ & $0.9-2.3$ & $\frac{5.0}{3.4-10.9}$ & $43.6-74.9$ \\
\hline Asya & $9 . \frac{11.6}{7-14.2}$ & $\frac{7.8}{5.6-11.0}$ & $1.2-3.2$ & $\frac{4.7}{1.7-9.6}$ & $32.0 \frac{48.8}{0-104.0}$ \\
\hline Bayana & $\frac{12.1}{10.7-14.0}$ & $\underline{8.8-11.6}$ & $\frac{1.5}{1.2-2.1}$ & $3 . \frac{6.0}{4-7.6}$ & $21.0-47.6$ \\
\hline Belka & $9.5-12.8$ & $\frac{7.3}{4.9-8.5}$ & $\frac{2.0}{1.4-2.7}$ & $\frac{3.8}{1.8-5.4}$ & $30 . \frac{46.8}{2-95.7}$ \\
\hline Valentinovka & $\frac{10.8}{8.5-13.0}$ & $\underline{6.9-10.3}$ & $\frac{2.1}{1.0-2.8}$ & $\underline{3.9}$ & $\begin{array}{c}29.2 \\
19.0-50.0\end{array}$ \\
\hline Vika & $\frac{10.8}{8.0-14.1}$ & $\frac{7.3}{4.7-10.2}$ & $\frac{1.8}{1.2-2.7}$ & $\frac{4.4}{2.2-10.0}$ & $\frac{47.2}{35.0-57.9}$ \\
\hline Gazelle & $\frac{12.2}{10.7-12.9}$ & $\frac{7.4}{6.3-9.0}$ & $\frac{2.4}{2.1-2.7}$ & $2.5-3.9$ & $2 \frac{28.4}{27.0-30.0}$ \\
\hline Dana & $9 \frac{11.7}{9.6-12.9}$ & $4.9 .9-9.6$ & $\frac{2.2}{1.9-2.7}$ & $\frac{3.1}{2.2-4.4}$ & $\begin{array}{c}30.0-54.7 \\
30.0-5\end{array}$ \\
\hline Dar Orla & $9 \frac{11.3}{9.6-14.0}$ & $\frac{7.8}{6.3-10.2}$ & $\frac{2.4}{2.1-2.7}$ & $2.3 .3-4.0$ & $29 \frac{39.6}{3-56.3}$ \\
\hline Marmeladnitsa & $9 \frac{12.1}{6.14 .9}$ & $\frac{5.9}{5.3-6.5}$ & $\frac{2.1}{1.5-2.8}$ & 2.1 .0 & $22 \frac{52.0}{22.9-66.6}$ \\
\hline $\begin{array}{l}\text { Orlovskaya } \\
\text { Zvezda }\end{array}$ & $\frac{12.1}{11.4-13.3}$ & 6.4 .12 & $\frac{2.7}{2.1-3.2}$ & $2.1-3.5$ & $18.7-58.8$ \\
\hline Orlovchanka & $8 . \frac{10.5}{3-12.9}$ & $5.4-9.1$ & $0.9-2.6$ & $\frac{4.6}{2.6-10.1}$ & $26.0-58.2$ \\
\hline Osipovskaya & $\frac{11.1}{8.8-14.7}$ & $5.1-9.3$ & $\frac{2.0}{1.0-2.8}$ & 2.2 .29 .0 & $22 \frac{37.1}{22.8-56.7}$ \\
\hline Roza & $9 . \frac{11.1}{9-12.9}$ & $\frac{8.1}{6.2-10.7}$ & $\frac{1.2}{0.9-1.8}$ & $\frac{7.1}{4.1-11.9}$ & $\frac{29.3}{17.0-62.4}$ \\
\hline Ustina, 2017 & 11.0 & 6.9 & 1.9 & 3.6 & 73.8 \\
\hline Average & $\frac{11.5}{8.0-14.9}$ & $\frac{7.4}{4.7-11.6}$ & $\frac{2.0}{0.9-3.2}$ & $\frac{4.2}{1.7-11.9}$ & $\frac{43.0}{17.0-104.0}$ \\
\hline
\end{tabular}

Notes: in the numerator - the average long-term value of the trait $(M)$, in the denominator - the variation of M in the years of research (min-max); SSM - soluble dry matters; SAI-sugar-acid index.

Berries of Asora, Asya, Bayana, Vika, Orlovchanka, and Roza varieties have high taste qualities. The low acid content of these varieties $(0.9-1.2 \%)$ and the highest sugar-acid index (7.6-11.9) were noted. According to the vitamin $\mathrm{C}$ content, the varieties Asora (43.6$74.9 \mathrm{mg} / 100 \mathrm{~g})$, Asya (32.0-104.0 mg/100 g), Belka (30.2-95.7 mg/100 g), Vika (35.0-57.9 $\mathrm{mg} / 100 \mathrm{~g})$, Marmeladnitsa (22.9-66.6 mg/100 g) were consistently distinguished (see Table 2). 


\section{Conclusion}

The following varieties were identified as sources of biochemistry: with a high content of soluble solid matters - Asya (14.2\%), Bayana (14.0\%), Vika (14.1\%), Dar Orla (14.0\%), Marmeladnitsa (14.9\%), Osipovskaya (14.7\%); sugars - Asya (11.0\%), Bayana (11.6\%), Roza (10.7\%); vitamin C - Asora (74.9 mg/100 g), Asya (104.0 mg/100 g), Belka (95.7 $\mathrm{mg} / 100 \mathrm{~g})$, Vika $(57.9 \mathrm{mg} / 100 \mathrm{~g})$, Marmeladnitsa $(66.6 \mathrm{mg} / 100 \mathrm{~g})$. The high sugar-acid index is typical for the varieties Asora (10.9), Orlovchanka (10.1), Roza (11.9); the varieties Asora, Orlovchanka, Roza $(0.9 \%)$ are characterized by a low acid content.

The 12 varieties Asora, Asya, Bayana, Valentinovka, Vika, Dana, Dar Orla, Marmeladnitsa, Orlovskaya Zvezda, Orlovchanka, Osipovskaya, and Roza were identified according to the complex of economically useful traits (yield, large-fruited, biochemical composition, resistance to gall aphids), which can be recommended for cultivation in the conditions of the Altai $\mathrm{Ob}$ region.

\section{References}

1. N.I. Nazaryuk, V.N. Sorokopudov, Nursery and private garden, 6(54), 18 (2018)

2. V.N. Sorokopudov, N.I. Nazaryuk, R.A. Nigmatzyanov, Agrarian Sector, 3(45), 160 (2020)

3. V.N. Sorokopudov, A.E. Solovyova, A.S. Smirnov, Red currant in the forest-steppe of the Ob region, 120 (2005)

4. F. Paprstein, J. Sedlak, J. Kaplan, Acta Horticulturae, 1133, 49 (2016)

5. G. Zdunić, K., Šavikin, D. Pljevljakušić, B. Djordjević, Nutritional Composition of Fruit Cultivars, 101 (2015)

6. A. Yareshchenko, Y. Tereshchenko, L. Pryimachuk, E. Todosyuk, Acta Horticulturae, 946, 177 (2012)

7. S. Pluta, Acta Horticulturae, 946, 27 (2012)

8. S. Strautina, I. Krasnova, I. Kalnina, V. Laugale, Acta Horticulturae, 946, 183 (2012)

9. S. Karhu, K. Antonius, S. Rantala, H. Kaldmäe, S. Pluta et al., Acta Horticulturae, 926, 27 (2012)

10. V. Nour, I. Trandafir, M.E. Ionica, Fruits, 66(5), 353 (2011)

11. State Register for Selection Achievements Admitted for Usage (National List), 1, 680 (2020)

12. S.M. Sabaraikina, T.S. Korobkova, V.N. Sorokopudov, Vestnik of the Russian agricultural science, 5, 31 (2007)

13. T.S. Korobkova, S.M. Sabaraikina, V.N. Sorokopudov, Red currant in Yakutia (systematics, geography, variability, introduction), 175 (2008)

14. V.I. Deineka, A.N. Chulkov, L.A. Deineka, V.N. Sorokopudov, Sorbtsionnye i Khromatograficheskie Protsessy, 15(4), 486 (2015)

15. V.N. Sorokopudov, L.A. Tokhtar, Biological features a red currant with introductions, $200(2013)$

16. S.D. Knyazev, L.V. Bayanova, Program and methodology of variety study of fruit, berry and nut crops, 351 (1999)

17. O.D. Golyaeva, O.V. Pomiculture and small fruits culture in Russia, 46, 103 (2016) 
18. O.D. Golyaeva, O.V. Kurashev, S.D. Knyazev, A.Yu. Bakhotskaya, Bulletin of the Russian agricultural science, 4, 41 (2020) 